\title{
An Inclination towards the Predicament of Violent Extremism Issues: A Case Study
}

\author{
Mohd Nazari Ismail, Nizlan Mohamed \\ Department of Business Policy \& Strategy, Faculty of Business \& Accountancy, \\ University of Malaya, Malaysia
}

\begin{abstract}
The violent extremism phenomenon has escalated without boundaries with unpredictable emerging outcomes. As such, whilst this volatile threat has increasingly affected most countries and establishments, the community within any government organization is also indulged with relentless specified cases. This qualitative case study intends to evaluate within the context of military personnel who have inclination towards violent extremism acts and issues. The study conducted is based on individual interviews among participants that had undergone the Task Force deradicalization program. The findings of the study showed distinct inter-connectivity factor between religiosity fundamentals, psychological manifestation and other management issues with the field of violent extremism. The output of this study resulted in substantial empirical data pertaining to personnel involvement in violent extremism realms and other issues within its perimeter. The impact of this study has unprecedented contribution to the organization in terms of improving counter violent extremism mechanism that is currently imposed in preventing and mitigating the terrorism dilemma. Consequently, the study justified the essentials to complement the war against global violent extremism and terrorism for any form of future engagements.
\end{abstract}

Key words: Counter Violent Extremism, Case Study, Evaluate, Inclination, Task Force Program, Religiosity Fundamentals, Psychological Manifestation, Management Issues.

\section{INTRODUCTION}

Relatively, the phenomenon of terrorism has become one of the extreme causes of the sufferings of mankind and remains as one of the greatest threats to societal well-being for the past decades [1]. The global terrorism threat has become more inconclusive, unprecedented and resilient in its operation [2]. Terrorism behavior are phenomenal issues which are unpredictable events influenced by organizational mechanism and interactional circumstances that occurs in complex environment [3]. The worldwide spread of terrorism implicates towards the growing challenges for international human resource management and transnational business [4] [5].

Conflicting with the principles of contemporary consensus, terrorism whether internal or globally is an act of extreme form of expression [6]. Indeed, it constitutes in breaching the most essential human rights fundamentals which is a right to life.
Furthermore, extensive and numerous numbers of scholars, journalists, writers and researchers are frequently feasible to undertake studies on violent extremism, but nevertheless they are not subjected to radicalization, or prone to engage in acts of terrorism. In contrary, recent experiences may even intensify the individual's repugnance of violent extremism and terrorism [7]. Terrorists attacks are deliberately aimed to raise individuals concern of fatality and physical injury. These terrorists severely damaging acts were executed towards the society to nurture indiscriminate violence and anxiety [8]. Therefore, the terrorism dilemma from these attacks establish a state of nature in the society by creating an environment of concern, fear, insecurity and constant suspicious towards violence extremism [8]. This terrorism dilemma and the abnormal condition was created by terrorists that purposely aimed towards citizens in peacetime situations [9]. Terrorism and violent extremism subjects have become an acquainted

Corresponding Author: Mohd Nazari Ismail, Department of Business Policy \& Strategy, Faculty of Business \& Accountancy, University of Malaya. 50630 Kuala Lumpur, Malaysia, E-mail: mdnazari@um.edu.my 


\section{Mohd Nazari \& Nizlan/International Journal of Business and Management, 3(2) 2019, Pages: 32-42}

menace of the contemporary world and is likely to remain as the main risks feature in all aspects of daily life

The threat of terrorism in Malaysia continues to pose a serious risk challenges as authorities grapple with the complexity of growing radicalization and strive to stay ahead of terrorists plotting attacks in the country. Since 2013, according to the authorities, it is reported that over 260 individuals have been arrested in accordance with violent extremism and terrorism-related offences and at least 14 planned terrorist attacks have been averted [10]. The need to establish security measures of counter-terrorism effort is a major priority. Relatively, the counter-terrorism efforts and counter violent extremism (CVE) measures has predominantly evolved due to extensive threat to the well-being of the community, instability of a nation, public interests, and foreign relations [11]

Inevitably, most government agencies, military organizations, non-government agencies and private sectors are seemingly involved to a certain extent, in preventing the circumstances from getting worse particularly in defending the sovereignty of a country. Paradoxically, despite allocating resources and defence expenditure, there is an increased community pressure on the government to take additional military approaches to combat terrorism issues [12]. Studies have shown that many actual conflict phenomena are instigated by terrorists' groups rather than the military forces of another country [13]. Threats on national security are continuously evolving depending on the degree of extremism inclination and intention of the other party, especially with the emergence of Islamic State (IS) or DAESH threats recently. The Task Force program is designed to scrutinize all issues pertaining to violence, extremism and terrorism in the organization. Various initiatives and strategies inclusive of risks mitigation are structured under the Task Force program including awareness proximity programs, media approaches (distributing pamphlets, posters), organizing seminars and conducting deradicalization program to overcome these negative phenomena [14]. Practically, the deradicalization program is constructed to restore the fundamental principles that disrepute the violent extremism ideologies of oneself thus justifies terrorists must be cognitively deterred from their radical belief system and mindset.

In accordance to this phenomenon, there are clearly issues that need further scrutinizing with regards to averting this matter from escalating. The aim of this article is to evaluate the inclination of military personnel towards the predicament of violent extremism issues and within its context. Subsequently, this study proposed some underlying suggestions that need to be considered in dealing with CVE threats within the organization perimeter for prevention measures.

\section{METHODOLOGY}

The essentiality of case studies in this qualitative research unlock the exploration and investigation of contemporary real-life phenomenon as seen from comprehensive related analysis of events or conditions, and its relationships. Case study research method is "as a pragmatic review that explores current situation within its actual context; when the parameters between the situation and context are not evidently proven and in which numerous causes of evidence are used" [13]. Case studies research is considered essential as it totally enable researchers to examine information and data at the micro level [14]. Although case studies research is debatable, it presents data of real-life situations and provide better insights into the detailed behaviors of the subjects of interest, which are the real essence towards understanding human dimension attributes.

\section{Identification Context}

All ten participants selected for this case study are military personnel that had undergone the deradicalization program under Task Force program. They are from diverse services/corps background and different scope of duty ranging from training, administration and technical duties specifications. This to substantiate the previous research that recommends having between five to twenty-five participants interviews for phenomenological studies [15]. Individual interviews are conducted with these participants that assumed periodically in a specific secluded location to attain specific information on the understanding of participants towards the subject matter. Face-to face interview is extensively recognized as an appropriate method for qualitative review to pursue insights of those who have endured or are experiencing the phenomenon [16][17]. The method of interview questions conducted involved semi structured questions that are open-ended, imposed to all specific personnel which focuses towards certain criteria in subject matter of the research. A semi-structured interview is a dominant data collection method because it has proven to be both versatile and flexible [18]. As for the purpose of this study, there are three basic questions directed to the participants excluding the other probing questions that may incur during the interview process. The basic questions poised to all participants in this study are as such: 


\section{Mohd Nazari \& Nizlan/International Journal of Business and Management, 3(2) 2019, Pages: $32-42$}

a. the inclination of personnel towards violent extremism and terrorism activities?

b. In your opinion, is the current CVE program adequate enough to prevent violent extremism threat from escalating in the organization?

c. What are your views or suggestions to improve the existing CVE program?

The overall evaluation flow of this study is represented in the diagram shown below in Table 1 .

Table 1

Evaluation Process

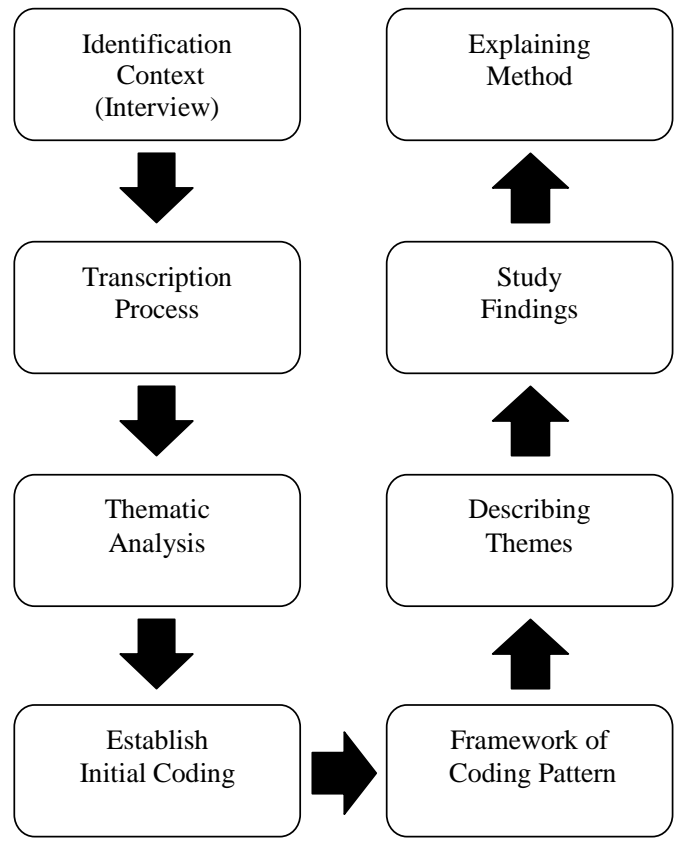

\section{Transcription process}

The transcription practices can be described subjected to two categories modes: naturalism, whereby every vocal expression is transcribed in every detail as possible, and de-naturalism, in which distinctive components of speech (e.g., nonverbal, pauses, stutters and involuntary vocalizations) are deleted [19]. In this study, the transcription process is undertaken immediately after the interview sessions are conducted to transcribe the data into written form. All interviews are conducted in a designated area and in civilian attire to enable a more conducive manner of conducting the interview. This allows the researcher to examine and digest the transcribed data conveyed from recordings device and written exactly as per the interviews conducted.

The transcription process of selecting texts which are prevalent to the objective of the study is vital rather than taken from the overall context [20]. By examining the transcription, at this stage the researcher is quite conversant with the content of the data, thus would be able to identify and distinguish patterns or repeating issues resulted from these interviews. These patterns are identified and recorded where it will be used when coding and checking for accuracy. Subsequently, on completion of the transcription process, the researcher's most significant task is to get hold and control over the data and indicate data that addresses the research question. This is actually the beginning of the coding process.

Thematic Analysis

Thematic analysis is considered to be the most typical way of analysis in qualitative research. It is a technique for identifying, analyzing, organizing, describing, and reporting themes found within a data set [21]. It is used in qualitative research, particularly in evaluating themes within data. This method highlights organization and rich explanation of the data set. Thematic analysis goes beyond simply counting phrases or words in a text and moves on to recognizing explicit and implicit notions within the data. Thematic analysis is a suitable method for investigating the perceptions of diverse research participants, addressing similarities and differences thus generating unexpected insights [21][22]. Coding is the prime procedure for emerging themes within the raw data by distinguishing vital moments in the data and encoding it before interpretation process.

The explanation of these codes can include linking theme existences, recognizing theme co-occurrence, and vividly demonstrating relationships between disparate themes. Most researchers contemplate thematic analysis as a beneficial qualitative analytic method in getting the particulars of meaning within a data set identified.

\section{Establish Initial Coding}

Establishing the initial codes is the next step in the thematic analysis whereby data that contains a list of items from the interview sessions that have a similar pattern is continuously reexamined. This allows the researcher to streamline and emphasis on particular attributes of the data [23]. This efficient way of establishing, and gaining meaningful parts of data as it relates to the research question is called coding. This coding process evolves through an inductive and deductive analysis and is not considered to be a linear process, in which codes emerge throughout the research process. Coding is a method that allows a researcher to manage and cluster equally coded data into categories or "relatives" because they 


\section{Mohd Nazari \& Nizlan/International Journal of Business and Management, 3(2) 2019, Pages: 32-42}

share some characteristics [24]. When conducting thematic analysis, the researcher attempts to explore beyond the surface interpretation of the data collected to make sense of the data and tell a truthful scenario of what it tries to imply.

The coding process consumes time and seldom completed during first time attempts. In this process, the researcher is enabling to strive and reassure to refine codes by adding, subtracting, combining or splitting potential codes. The coding process have shown the significance of quick retrieval, competent relating of data and create descriptive models, do not prevent contextualized and rigorous qualitative studies [25]. Some terminologies may be used by participants during the interview and can be used as a reference point of their experiences during the interview. These codes will facilitate the researcher's ability to locate fragments of data later in the process and identify the reason to include them. Codes are primary, but not exclusive, which are used to retrieve and categorize similar data portions in order for the researcher to identify, extract and cluster the segments relating to a particular research questions, construct, hypothesis and themes [26].

Initial coding sets the stage for detailed analysis later by allowing the researcher to reorganize the data according to the ideas that have been obtained throughout the process. Throughout the coding progression, attentive focus needs to be carefully monitored on each data item to enable the identification of overlooked repeated patterns. The portion of data to be coded during this stage can range in eminence from a single word to a full sentence, to the whole sheet of text to a stream of moving descriptions [24]. Coding process for individuals' interviews as many times as possible may seem irrelevant but can potentially be crucial later in the analysis process.

Ultimately, some data reduction from compilation of sentences process also involves coding method. The reduction of codes is started by assigning tags or labels to the data set based on the research questions. In this stage, condensing large data sets into smaller units permits further analysis of the data by creating useful categories. The act of coding requires the researcher to put on the researcher's analytic lens [24]. Nevertheless, the perception and interpretation of what is happening in the data depends on what type of filter covers that lens. The researcher has identified some variety of coding categories in the process of executing this study.

Coding consequently can improve expansion, transformation and restructuring of data thus helps to find more eventualities for data analysis. Based on the interview conducted by the researcher, there are three types of coding namely the descriptive coding, evaluation coding and values coding. Listed below are the essential sentences phrase of the interview that are feasible for initial coding identification and the coding categories. Principally, from this table, the researcher has now ascertained the initial coding accumulated from the transcription process to further continue with the next process. All the pertinent data collected are systematically arranged in a framework for the coding pattern that leads to categories and theme classification.

\section{a. Participant 1}

\begin{tabular}{lc}
\hline Interview transcription text & Types of Coding \\
\hline "He communicated with the & method \\
audience in an excellent way, & (descriptive coding) \\
explaining on the topic of IS & \\
especially anything to do with & \\
IS" & \\
"IS and in terms of possession & materials \\
of flag, reading materials, & (descriptive coding) \\
posters, car stickers or & \\
anything concerning militants & \\
group" & \\
"they should emphasize more & management issues \\
on conducting road show & (descriptive coding) \\
program frequently in various & \\
military camps to educate & \\
soldiers." &
\end{tabular}

b. Participant 2

\begin{tabular}{lc}
\hline Interview transcription text & Types of Coding \\
\hline "...too obsessed with Islamic & religiosity \\
teachings even though there are & fundamentals \\
negative elements that are & (values coding) \\
against the $\quad$ Islamic & \\
fundamentals & \\
"Subsequently, it is also about & human rights injustice \\
humanity issues, discrimination & (values coding) \\
$\begin{array}{l}\text { and oppression of mankind that } \\
\text { are associated with terrorism" }\end{array}$ & \\
\hline
\end{tabular}

c. Participant 3

\begin{tabular}{lc}
\hline Interview transcription text & Types of Coding \\
\hline "this program accomplished in & educate personnel \\
educating military personnel to & (evaluation coding) \\
be more vigilant in their & \\
decision making process" & \\
"the main impact of this & media social usage \\
program is the usage of media & (descriptive coding) \\
social as a medium of \\
interaction for this group to \\
spread their ideologies..." \\
\multicolumn{4}{c}{} \\
"they may offer certain \\
lucrative reward or using the \\
method of a shortcut to heaven \\
\hline
\end{tabular}


Mohd Nazari \& Nizlan/International Journal of Business and Management, 3(2) 2019, Pages: 32-42

attraction"

d.

Participant 4

\begin{tabular}{|c|c|}
\hline Interview transcription text & Types of Coding \\
\hline $\begin{array}{l}\text { "how IS communicates, their } \\
\text { war tactics, conducting their } \\
\text { close battle and in urban } \\
\text { areas....??" }\end{array}$ & $\begin{array}{c}\text { seek information } \\
\text { (evaluation coding) }\end{array}$ \\
\hline $\begin{array}{l}\text { "misunderstood some of the } \\
\text { verse in the Al-Quran and } \\
\text { interpret wrongly..." }\end{array}$ & $\begin{array}{l}\text { religiosity } \\
\text { fundamentals } \\
\text { (values coding) }\end{array}$ \\
\hline $\begin{array}{l}\text { "more systematic approaches } \\
\text { including psychology subject. in } \\
\text { videos, movies and pictures that } \\
\text { associates with the ideology..," }\end{array}$ & $\begin{array}{l}\text { psychology } \\
\text { inclination } \\
\text { (evaluation coding) }\end{array}$ \\
\hline $\begin{array}{l}\text { "selected individuals possessed } \\
\text { high motivation spirit which is } \\
\text { the quality of a good soldier.." }\end{array}$ & $\begin{array}{c}\text { individuals' } \\
\text { characteristics } \\
\text { (descriptive coding) }\end{array}$ \\
\hline $\begin{array}{l}\text { "the important thing is to } \\
\text { enforce the rules, regulation } \\
\text { and laws firmly according to } \\
\text { the armed force..." }\end{array}$ & $\begin{array}{l}\text { enforcement value } \\
\text { (descriptive coding) }\end{array}$ \\
\hline $\begin{array}{l}\text { "the management system of the } \\
\text { unit plays a vital role to ensure } \\
\text { survivability and sustainability } \\
\text { of all personnel to prevail..." }\end{array}$ & $\begin{array}{l}\text { managing procedure } \\
\text { (evaluation coding) }\end{array}$ \\
\hline
\end{tabular}

\section{e. Participant 5}

\begin{tabular}{lc}
\hline Interview transcription text & Types of Coding \\
\hline "I am interested with Hizbut & religiosity \\
Tahrir as their jihad is to & fundamentals \\
uphold the Islamic khilafiyyah & (values coding) \\
ruling..." & \\
"It is more on psychological & psychology \\
influence to restore the muslim & inclination \\
people beliefs, their ideology & (evaluation coding) \\
and thinking of Islamic faith..." & \\
"this program to be conducted & administrative aspect \\
frequently at unit level and & (descriptive coding) \\
attended by all personnel... & \\
" to monitor all information in & monitoring medium \\
social media platform, emails, & (descriptive coding) \\
WhatsApp of military personnel & \\
"the unit management and the & management issues \\
religious personnel should & (evaluation coding) \\
conduct talk or lectures on all & \\
current affairs issue to get & \\
abreast of the violent extremism \\
matters..."
\end{tabular}

\section{f. Participant 6}

\begin{tabular}{|c|c|}
\hline Interview transcription text & Types of Coding \\
\hline $\begin{array}{l}\text { "the subject of Islamic studies } \\
\text { need to be emphasized on } \\
\text { strengthening aqedah among } \\
\text { muslim military personnel.... }\end{array}$ & $\begin{array}{l}\text { religiosity } \\
\text { fundamentals } \\
\text { (values coding) }\end{array}$ \\
\hline $\begin{array}{l}\text { "behavioral and mind studies } \\
\text { should be included in the } \\
\text { program in order to understand } \\
\text { their psychological state before } \\
\text { they embark towards bigger } \\
\text { issues in their life.." }\end{array}$ & $\begin{array}{l}\text { psychology inclination } \\
\text { (evaluation coding) }\end{array}$ \\
\hline
\end{tabular}

g. Participant 7

\begin{tabular}{lc}
\hline Interview transcription text & Types of Coding \\
\hline "I was supporting the Aman & humanity issues \\
(values coding) \\
wanted me to join the NGO \\
group, humanitarian support \\
there.." \\
"you need to possess more \\
knowledge on psychology \\
perspectives in violent & (evaluation coding) \\
extremism field. Otherwise, you & \\
will be dragged and influenced & \\
by this propaganda..." & \\
"the most important aspects & religiosity \\
here is strong religious & fundamentals \\
education to hinder you from & (value coding) \\
the IS/DAESH ideology..." & \\
"the IS/DAESH are using & misinformation of \\
hadiths, manipulated it by & religiosity \\
saying jihad for Islam is sacred & fundamentals \\
and granted martyr if you are & (values coding) \\
killed in war, it is a short cut to & \\
heaven, which under that & \\
pretext is untrue... " & \\
"we should form up a prevention measures \\
monitoring team and enforce \\
counter measures for early \\
detection of any military \\
personnel alleged or prone to \\
support violent extremism \\
domain..." coding) \\
\hline
\end{tabular}

h. Participant 8

\begin{tabular}{lc}
\hline \multicolumn{1}{c}{ Interview transcription text } & Types of Coding \\
\hline "I came across anti-shia group & explaining symptom \\
page, then I joined this group, & (evaluation coding) \\
to know the wrongdoing of & \\
shia" & religiosity \\
"we should understand and be & fundamentals \\
exposed to jihad, comprehend & (values coding) \\
the predicament of jihad and & \\
digest it from true Islamic & \\
teachings..." &
\end{tabular}


Mohd Nazari \& Nizlan/International Journal of Business and Management, 3(2) 2019, Pages: 32-42

"If the foundation of religious
studies is inadequate and
lacking, you seek other
resources to understand the
topic which may lead you to
(values coding)
understanding of jihad in
Islam"
"the method of giving
information on the issue of psychology education
IS/DAESH in Syria should be
conducted frequently with
adequate and accurate
resources especially from coding)
mindset and behavior
aspect... "
"in bigger perspectives, the
ministry should also have a
grand strategy of CVE, the
needs to have collaborative and
form a synergy among agencies
to combat against these violent
extremism threat in future
undertakings"

\section{i. $\quad$ Participant 9}

\begin{tabular}{lc}
\hline Interview transcription text & Types of Coding \\
\hline "explain about the danger of & $\begin{array}{c}\text { media social usage } \\
\text { (descriptive coding) }\end{array}$ \\
using social media platforms & \\
such as Facebook to promote & \\
any violence and extremists" & \\
activities...," & \\
"some exposure towards & religiosity and \\
understanding the actions, psychology education \\
feelings and mental state of all & (evaluation coding) \\
the participants, the most & \\
important aspect is to & \\
emphasize on the true authentic & \\
Islamic fundamentals" & \\
"the influence of internet, other & information \\
platforms give avenues, to & dissemination \\
develop the desire and curiosity & (descriptive coding) \\
to know something and to get & \\
more information of certain & \\
things make them explore \\
uncharacteristically...."
\end{tabular}

\section{j. Participant 10}

\begin{tabular}{|c|c|}
\hline Interview transcription text & Types of Coding \\
\hline $\begin{array}{l}\text { "I was intrigued with Al- } \\
\text { Qassam army, which is to } \\
\text { defend Islam truthfully ..." }\end{array}$ & $\begin{array}{c}\text { inclination of } \\
\text { intention (descriptive } \\
\text { coding) }\end{array}$ \\
\hline $\begin{array}{l}\text { "but they didn't explain the } \\
\text { details of jihad, so I would } \\
\text { foresee the program should } \\
\text { include the tawhid aspects in } \\
\text { jihad..." }\end{array}$ & $\begin{array}{l}\text { religiosity } \\
\text { fundamentals } \\
\text { (values coding) }\end{array}$ \\
\hline
\end{tabular}

\begin{tabular}{|c|c|}
\hline $\begin{array}{l}\text { "I was intrigued with } \\
\text { Al-Qassam army, which is to } \\
\text { defend Islam truthfully..." }\end{array}$ & $\begin{array}{c}\text { inclination of } \\
\text { intention } \\
\text { (descriptive coding) }\end{array}$ \\
\hline $\begin{array}{l}\text { "but they didn't explain the } \\
\text { details of jihad, so I would } \\
\text { foresee the program should }\end{array}$ & $\begin{array}{c}\text { religiosity } \\
\text { fundamentals } \\
\text { (values coding) }\end{array}$ \\
\hline
\end{tabular}

include the tawhid aspects in jihad..."

"the program should be extended to two weeks so that we can maximize the program schedule with Islamic teachings, psychology subject and so on ..."

"all these military personnel do not really understand the religious aspects wholeheartedly with the right Islamic fundamentals. Therefore, they do not really understand jihad in its true context..."

"but the need to increase and include certain subjects towards behavior, attitude, and action in the module are essential"

"their patriotic spirit as military personnel made them embark on a need of realism or actualization by performing this act in Syria"

"the management team in the unit should have early precaution and detect any military personnel that showed symptoms indicating any negative activities, the unit should adopt a comprehensive system..."

\section{Framework of Coding Pattern}

The researcher has now identified the coding pattern for this interview process. Different patterns of coding may emerge if the research process is prolonged. Therefore, the researcher is deemed to always be aware and re-evaluates all interviews conducted to incorporate the types of coding with the coding pattern identified and continue with the next process. The segmented types of coding constructed earlier would be relevant and beneficial for the researcher to proceed in determining the main themes or concepts. Subsequently, in the next process, the researcher would streamline the coding process as depicted in the table below which comprises of first cycle coding, second cycle coding, categories and the main themes identified in the interviews [24]: 
Table 2

Framework Coding Pattern

\begin{tabular}{|c|c|c|c|}
\hline First cycle coding & Second cycle coding & Categories & $\begin{array}{l}\text { Main } \\
\text { themes/concept }\end{array}$ \\
\hline $\begin{array}{l}\text { Materials, method } \\
\text { Syria } \\
\text { Violent extremism } \\
\text { Militants } \\
\text { IS/DAESH } \\
\text { Hizbut Tahrir } \\
\text { Aman Palestine, Al Qassam }\end{array}$ & $\begin{array}{l}\text { Propaganda } \\
\text { Extremists group }\end{array}$ & $\begin{array}{l}\text { Strategy } \\
\text { Violent extremism }\end{array}$ & $\begin{array}{l}\text { Counter } \\
\text { Violent } \\
\text { Extremism } \\
\text { Strategy }\end{array}$ \\
\hline $\begin{array}{l}\text { Discrimination } \\
\text { Involvement, early precaution, } \\
\text { detection } \\
\text { Educate/training } \\
\text { Enforcement } \\
\text { Procedural system } \\
\text { Rules/regulations } \\
\text { Awareness/analysis } \\
\text { Collaborate/synergy }\end{array}$ & $\begin{array}{l}\text { Structural execution } \\
\text { System }\end{array}$ & $\begin{array}{l}\text { Decisive ways } \\
\text { Systematic method }\end{array}$ & $\begin{array}{l}\text { Systematic } \\
\text { mechanism } \\
\text { approach }\end{array}$ \\
\hline $\begin{array}{l}\text { Military personnel } \\
\text { Patriotism spirit } \\
\text { Individuals values/characteristics } \\
\text { Understanding } \\
\text { Faith/beliefs } \\
\text { Islamic studies/hadiths } \\
\text { Jihad/struggle } \\
\text { Al-quran, aqeedah/tauhid } \\
\text { Khilaffah/khalifah }\end{array}$ & $\begin{array}{l}\text { Ideologies } \\
\text { Principle } \\
\text { Religiosity essentials }\end{array}$ & $\begin{array}{l}\text { Leadership } \\
\text { Defining identity }\end{array}$ & $\begin{array}{l}\text { Human identity } \\
\text { fundamentals }\end{array}$ \\
\hline $\begin{array}{l}\text { Attitude, vigilant } \\
\text { Desire, curiosity, deprive, oppress } \\
\text { Hearts and mind } \\
\text { Political agenda } \\
\text { Feelings/confusion } \\
\text { Supportive/manipulative }\end{array}$ & Human perception & Human behavior & $\begin{array}{l}\text { Psychological } \\
\text { Manifestation }\end{array}$ \\
\hline $\begin{array}{l}\text { Unprofessionalism } \\
\text { Manifestation } \\
\text { Negative activities } \\
\text { Root problem/symptoms } \\
\text { Reward/charity/benefit } \\
\text { Security/safety } \\
\text { Realism/actualization } \\
\text { Monitoring/managing }\end{array}$ & $\begin{array}{l}\text { Prevention } \\
\text { Administrative } \\
\text { Responsibility }\end{array}$ & $\begin{array}{l}\text { Planning schedule } \\
\text { Organization commitment }\end{array}$ & $\begin{array}{l}\text { Internal } \\
\text { management } \\
\text { issues }\end{array}$ \\
\hline $\begin{array}{l}\text { Internet/Facebook } \\
\text { Resources/exposure } \\
\text { Netizens/youngsters } \\
\text { Adequate/inadequate } \\
\text { Current issue affairs } \\
\text { Social media } \\
\text { Information dissemination }\end{array}$ & $\begin{array}{l}\text { Interaction } \\
\text { Educate/awareness }\end{array}$ & Communication proclivity & $\begin{array}{l}\text { Effective } \\
\text { Education } \\
\text { Method }\end{array}$ \\
\hline
\end{tabular}

As shown above, there are numerous initial data and information collected whereby the researcher has established the coding pattern, categories and continues to ascertain the main themes of the 
Mohd Nazari \& Nizlan/ International Journal of Business and Management, 3(2) 2019, Pages: $32-42$

discourse to be examined for further prevalence of this data analysis process.

Ultimately, after conducting the framework process, the researcher has identified the main themes of the study which are:

$\begin{array}{ll}\text { a. } & \text { Counter violent extremism strategy } \\ \text { b. } & \text { Systematic mechanism approach } \\ \text { c. } & \text { Human identity fundamentals } \\ \text { d } & \text { Psychological manifestation } \\ \text { e. } & \text { Internal management issues } \\ \text { f. } & \text { Effective education method }\end{array}$

\section{Describing Theme}

The themes selected are based on the process of coding pattern generated in the study. All these themes selected are unique and specific in its own character. The definition of theme is a beneficial discipline to engage as it focuses on the boundaries of the themes to distil the essence of what the themes constitutes [27]. Every theme has a purpose, clear focus, scope, relatively distinct and collectively deliver worth, articulate and meaningful images of main patterns in the data that discourses the research questions [27]. The definition of the six themes identified in this study based on participants understanding with inserted analytical analysis is as follows:

\section{a. Theme: Counter Violent Extremism Strategy}

The overarching theme that describes the planning and composition of a strategized program encompasses the overall CVE strategy plan. The grand strategy of CVE planning should be formulated at national level, subsequently all government agencies and organizations should adopt the CVE planning to be executed comprehensively by stages. Participants are exposed to the counter violent extremism program in distinct ways, both in positive and negative aspects. Some mentioned vast improvements need to be executed on the method of presentation, focus primarily on CVE method, without diverting to other issues such as politics, political leader and government ruling party, whilst others mentioned the program achieved its desired objectives. A primary composite of method and materials of CVE issues are explained in the program. Inadequate explanation of violent extremism is taken from unreliable sources such as social media platforms. Paradoxically, the implementation of the deradicalization program should be revised and strategically scrutinized within its context. In the context of the mode of presentation on the information relating to the characteristics, history, ideology, strategy and development of IS/DAESH, it was comprehensive and well executed while the proximity of neutrality should be instilled. The second cycle coding is developed considering the explanation primarily on militant extremists' groups, the propaganda and methodology imposed are relatively alarming. The CVE modus operandi in future circumstances and expectations are not well explored as well as not recognizing other specific mechanism imposed by other countries to prevent this phenomenon from escalating. The approach in this categorization of countering violent extremism efforts are highlighted but some modification of the program needs to be reviewed along with specific development of current CVE measures undertaken by other countries or organization worldwide.

\section{b. Theme: Systematic Mechanism Approach}

The overarching theme elaborates the necessity to formulate a systematic mechanism that should be undertaken at any organization to have early detection and preventive measures. This approach may be implemented at training establishments or unit level (early stage) to scrutinize the involvement of personnel in the DAESH/IS phenomenon. As such, this approach may comprise of comprehensive structural method and evaluation procedural mechanism lead by a team (may comprises of officers and other personnel of diverse ranks) for continuous assessment and monitoring purposes. The program certainly educates the audiences to digest and understand the cause root of terrorism, the methodology of IS/DAESH organization to promote violent extremism and cause fear among public citizen across the world. The second cycle coding also identified subject on perception, structural execution for counter measures effort in addressing the issues of aggression behavior and negative perspectives committed by these groups. The categories segment streamlines towards the decisive method and methodical way of identifying personnel that have inclination towards performing violent extremism or any associated act along the perimeter.

\section{c. Theme: Human Identity}

The overarching theme elaborates concern regarding military personnel or netizens that are too obsessed with Islamic teachings even though there are negative elements that are against the faith and Islamic beliefs which they are aware of, but still obliged to follow these group of people who are wide spreading their ideologies to gain support from the people. The participant's understanding of violent extremism can be manipulated or interpreted differently using the name of faith/beliefs from a deceit way. From his judgement, the personnel may be misguided or in state of confusion to prove himself worthwhile by joining the group with the intention of getting 


\section{Mohd Nazari \& Nizlan/International Journal of Business and Management, 3(2) 2019, Pages: 32-42}

jihad and wish to be placed in heaven in the life hereafter. Military personnel who are directly or indirectly involved in this groups, may be influenced by the ideologies promulgated by IS or DAESH, in manifestation of promising all the good endings in life hereafter. The probability may incur for some religious personnel involved in this violent extremism encounter because they devote their struggle of jihad aggressively in a peculiar manner by understanding Islam from different perspectives. The extremist's groups of IS/DAESH are using religiosity (Islam) as their main reason of struggle but actually in real fact, it contradicts and does not reflects towards upholding the true Islamic teachings as their main endeavor but manipulate the situation using the name of Islamic struggle and take advantage of the process. They manipulated their struggle by using certain verses in the Al-Quran and swayed it to justify their teachings especially concerning the act of martyr. Obviously, there are discrepancies in the perception to portray oneself towards submission and worship of Islam from this perspective, since it is known that in truth, Islam is ad-deen or a religion of peace. This implicates towards identifying their true self-identity or discovering their own beliefs/faith dominance that lead to understanding the human identity fundamentals.

\section{d. Theme: Psychological Manifestation}

The overarching theme explains the participants' views on violent extremism act to be associated with psychological aspects of human capital, reaction, feelings and desire towards action-based performance. This issue of violent extremism is very complicated, because it deals with human behavior, hearts and mind of people, mental state, methodology and propaganda, even though there are no detainees, but necessary precaution measures need to be enforced. At the same time, this theme may also be incorporated with the systematic mechanism approach by implementing the specific psychometric test towards violent extremism threat imposed in the comprehensive structural method for evaluation purposes. Indirectly the method of this IS/DAESH groups to spread their ideology is more towards applying the psychological attraction in which they offer certain lucrative rewards, besides promising a shortcut path to heaven, to lure mostly youngsters to be part of them through the influence of social media correspondence. In terms of dealing with soldiers in camps, leaders are more tactful in their action pertaining to this sensitive issue that involves security, thus making them observe and monitor the soldiers frequently. Any observation of unusual behavior will be met with thorough investigation and scrutinization. Suspected military personnel in these activities will undergo counselling session domestically, abide with security procedures stated and subsequently reported to higher authority for consultation and further action taken. Previously, this Task Force program is conducted by segregating muslim and non-muslim soldiers, but now it is centralized to all soldiers regardless of religion, races or ethnic group. The issue of discrimination does not arise here hence all soldiers are treated equally and able to gives their views openly in a specific location. All the abovementioned factors have indicated that the psychology tendency is the criteria dealing with human interaction and behavior aspects.

\section{e. Theme: Internal management issues}

The overarching theme substantially reflects on the necessity of a standard management system to be implemented in the organization. The program should be more strategy oriented by virtue of flexibility schedule planning organized by Task Force team to educate all personnel. The subject and method of delivering lectures should also be improvised and updated in terms of data compilation. Across the themes, the involvement of other prominent presenters such as law experts and religious speakers should also be included in the program to give significant insight, professional views and other implications relating to violent extremism matters. The unit management cell should conduct talk or lectures at least once a week and expose military personnel to current issues and affairs concerning violent extremism matters, especially in Syria or any middle east countries, explaining the ongoing incident, the current condition there and probably an analysis of the situation. The main focus should be to educate the audiences on the subject matter of violent extremism and within terrorism compound thus emphasize on preventive measures imposed as deterrence initiatives to the organization.

\section{f. Themes: Effective education method}

The overarching themes describe towards the significance of effective education approach to be applied in the overall system to ensure a positive impact on this issue. Effective and proper knowledge insights with reliable education system are essential for the benefit of all personnel in the organization. Some personnel may involve either directly or indirectly in violent extremism activities based on the influence of social media as this platform offer diverse avenues to develop the desire and curiosity to acquire more information hence explore uncharacteristically. The imparting of knowledge may vary according to the subject specification such as religiosity, violent extremism and terrorism, psychology subject, current affairs and other pertinent matters. Therefore, it is crucial 


\section{Mohd Nazari \& Nizlan/International Journal of Business and Management, 3(2) 2019, Pages: 32-42}

to convey and expose personnel with the accurate and sufficient information to enable the personnel in differentiating what is wrong and what is right in a decision-making process. In terms of communication dissemination, an enforcement team either from field security detachment or the unit intelligence cell, should seriously monitor all information on the social media platform, WhatsApp, emails and other form of online information among personnel or react immediately if there are any suspicious connotations.

All the themes definition stated above are the data analytically extracted from the interview transcription and further interpretation by the researcher. This approach is more descriptive in terms of presenting the story of data input that essentially connects to the exact interpretation of the participants. Subsequently, the researcher intends to analyze these themes and linking it with empirical studies conducted prior to this study that is associated with theories and previous studies in different avenues.

\section{DISCUSSION}

From the case study, the findings showed strong interconnectivity across all of the themes. Instead of having a separate impact on the actions of the individuals, the themes are said to intensify and escalates certain themes. However, the two prominent factors are human identity fundamentals and psychological manifestation aspect. The combination of these two themes is seen to have the greatest role in the involvement of individuals in terrorism. In terms of identity fundamentals, individuals tend to view religion as an extension of themselves. Thus, a skewed understanding and embodiment of the religion is detrimental to not only themselves, but also to the surroundings. Within the terrorism context, the connection between Islam and jihad is undeniable. Consequently, using such thinking, terrorist organization may manipulate the meaning and translation of the verses in the Al-Quran, obscuring and shifting the individual's viewpoint of certain fundamentals and rights. Coupled with the strong identity fundamentals, individuals who are prone to different ideologies, concepts and ideas are more susceptible to the lure of joining a terrorism group. An approach that is able to fully understand the psychological capabilities and tendencies of an individual should be one of the key elements in the employment process. This will help formulate plans to predict any future intrusion from third parties. Evidently, a systematic mechanism approach can be formulated. Currently, all of the big international and national companies are requiring a psychometric test to be taken by all future employees to see the personality traits that drives and motivates them to be successful. From this, a comprehensive view of the necessary elements to ensure a motivated and happy individual can be acquired.

The desire to seek understanding, solace and knowledge from third parties' can be dangerous because it opens up potential to other vulnerabilities such as false information and ideologies. This is connected under the theme effective education method. The influence from external factors such as social media may affect the decision making regarding their own principles and stands. The acquiring of information can also open doors to other extreme manipulators who perform unlawful acts. Thus, an effective education method that teaches correct religious perspective and practices neutrality in terms of opinions should be put into place. Coupled with this, an efficient management system needs to be implemented. A standardized management system within the organizations which includes a more diverse and experienced group of speakers can help cover greater exposure regarding terrorism issues and improves relatability. From this pertinent aspect, another theme emerges - counter violent extremism. Good counter violence extremism measures must be coupled with a strong and efficient management system. Within the teaching scope of counter violent extremism, the importance to look at the situation in a rational and neutral manner needs to be emphasized and embedded. Conclusively, the themes are interconnected and the improvement of one theme will create a domino effect in ensuring the betterment of all themes. Nevertheless, the researcher has not determined undeniably how these circumstances, features, or cognitions may shift to encourage disengagement from violence extremism realm [28]. Hence, with all these significant themes, it will enable the researcher to move ahead in utilizing the appropriate approach in explaining the method in this study.

\section{Explaining Method}

One of the methods in identifying the qualitative analysis from this data collection analysis is explaining. Data displays can be constructed in three types of explanatory matrices which are explaining interrelationship, explaining change and explaining causation [26]. The matrices are designed to enable a clear story flow of antecedents, sequences and outcomes. Basically, a good explaining method is to link the explanations given by the participants in the interview with the explanations the researcher develops in the whole process. Nevertheless, this link resulted shortcomings in the process of evaluation. As for this study, the researcher has selected the 
Mohd Nazari \& Nizlan/ International Journal of Business and Management, 3(2) 2019, Pages: 32-42

explaining change method to visualize the consequences of the issues by presenting the case dynamics matrix table. The case dynamics matrix table demonstrates a set of forces for change and traces the consequential processes and outcomes
[26]. The basic principle outlined is one of the preliminary explanations that seem relevant to address a particular question. The case dynamics matrix table for this study is to evaluate the CVE program presented as such:

Table 3

Case Dynamics Matrix: Evaluation of CVE program

\begin{tabular}{|c|c|c|c|}
\hline $\begin{array}{c}\text { Problems in CVE } \\
\text { Programs } \\
\end{array}$ & $\begin{array}{c}\text { Underlying Issues - } \\
\text { Researcher View }\end{array}$ & How to Manage It & $\begin{array}{c}\text { How Resolved: Type of } \\
\text { Resulting Change }\end{array}$ \\
\hline $\begin{array}{l}\text { Conflicting presentation } \\
\text { mixing core elements of } \\
\text { CVE programs with } \\
\text { politics matters }\end{array}$ & $\begin{array}{l}\text { Diverse duties. } \\
\text { Connectivity between } \\
\text { violent extremism and } \\
\text { politics is essential. }\end{array}$ & $\begin{array}{l}\text { Perform the talk } \\
\text { meticulously, focus towards } \\
\text { main criteria of CVE } \\
\text { approach, informative and } \\
\text { preventive measures }\end{array}$ & $\begin{array}{l}\text { Re-evaluate on presenting } \\
\text { method, get feedback on } \\
\text { outcomes of talk, discuss with } \\
\text { other authorities to create } \\
\text { harmonious presentation }(\mathrm{P})\end{array}$ \\
\hline $\begin{array}{l}\text { Implicating prominent } \\
\text { religious political leader } \\
\text { in lecture - unsuitable } \\
\text { in this context }\end{array}$ & $\begin{array}{l}\text { Indecisive duties. To divert } \\
\text { or capture audience } \\
\text { attention indirectly. }\end{array}$ & $\begin{array}{l}\text { Express concerns and } \\
\text { reacted neutral. Avoid } \\
\text { unnecessary or sensitive } \\
\text { issues discuss in open forum }\end{array}$ & $\begin{array}{l}\text { Segregate religiosity issues to } \\
\text { other authorities to handle. } \\
\text { Concentrate on educating } \\
\text { personnel in CVE matters (P) }\end{array}$ \\
\hline $\begin{array}{l}\text { The way speaker } \\
\text { presented his talk - } \\
\text { quite arrogant, and } \\
\text { unsupportive feedback } \\
\text { from audiences }\end{array}$ & $\begin{array}{l}\text { Command and Control. } \\
\text { Firm and affirmative way } \\
\text { of Leadership. }\end{array}$ & $\begin{array}{l}\text { Depends on the crowd or } \\
\text { audience capacity. Do not } \\
\text { act inconsiderable, to gauge } \\
\text { strong support from the } \\
\text { audience participation }\end{array}$ & $\begin{array}{l}\text { Institutionalize the management } \\
\text { team of Task Force. Indulge } \\
\text { firm support from higher } \\
\text { authority to be flexible and } \\
\text { innovative way of presenting the } \\
\text { talk. (E). }\end{array}$ \\
\hline $\begin{array}{l}\text { Information on violent } \\
\text { extremists group } \\
\text { perceived in electronic } \\
\text { media transmission not } \\
\text { verified authentic } \\
\text { especially in social } \\
\text { media platform/ }\end{array}$ & $\begin{array}{l}\text { Specified Duties. } \\
\text { Explaining } \\
\text { interrelationship of CVE } \\
\text { and other issues }\end{array}$ & $\begin{array}{l}\text { The program due to } \\
\text { highlight essential } \\
\text { information gathered, data } \\
\text { on militants, violent } \\
\text { extremism groups to be } \\
\text { circulated to all military and } \\
\text { civilian personnel }\end{array}$ & $\begin{array}{l}\text { Task Force remain vital and } \\
\text { provide updated and latest } \\
\text { information on violent } \\
\text { extremism and terrorism, } \\
\text { frequent program conducted } \\
\text { periodically with creative } \\
\text { method of presentation }(\mathrm{P}) \text {. }\end{array}$ \\
\hline $\begin{array}{l}\text { Lack of extensive and } \\
\text { thorough management } \\
\text { mechanism to detect } \\
\text { military personnel } \\
\text { involved in violent } \\
\text { extremism activities }\end{array}$ & $\begin{array}{l}\text { Autonomy. Reflective on } \\
\text { extra effort should } \\
\text { emphasize to this CVE } \\
\text { program }\end{array}$ & $\begin{array}{l}\text { Discussion between Task } \\
\text { force team and all military } \\
\text { unit are crucial to eliminate } \\
\text { any forms of violent } \\
\text { extremism to escalate, } \\
\text { detection early, management } \\
\text { teams in unit to progress }\end{array}$ & $\begin{array}{l}\text { Latest policy, procedures and } \\
\text { documentation on CVE to } \\
\text { disseminate for early prevention } \\
\text { measures undertaken. Maximum } \\
\text { penalty imposed for committing } \\
\text { the offences. (S) }\end{array}$ \\
\hline
\end{tabular}

The summary of the table explained clearly the concept of explaining change imposed in the data collection process. It gives a broad idea for the researcher to anticipate other circumstances or foresee any expectations that may arise during the process of the interview session. Here, the researcher can identify and ascertain shortcomings of CVE methods under the task management duties that need to be re-evaluated according to the level of command and leadership of an organization. Essentially, from this avenue, it gives a sense of analytical analysis towards assimilating the main themes identified earlier in the coding process with this case dynamics matrix in confronting this issue. The prominent aspect to consider here is directed towards the change management process in the organization for decisive outcomes planning.
Mindfully, the researcher may also expect other diverse pragmatic interferences such as organizational culture or low budget capabilities in addressing this matter comprehensively.

\section{RECOMMENDATIONS}

It is imperative for this qualitative research to extend future direction of the study either from recommendations or implications [29]. The study has certainly imposed an impact towards research diagnosis of scrutinizing extremism, violence and terrorism studies in any organization environment. The effectiveness of CVE programs is inter-related with how the CVE programs are interpreted [30]. An inclusive research will broaden the horizons of researchers, thinkers and writers in any 
Mohd Nazari \& Nizlan/International Journal of Business and Management, 3(2) 2019, Pages: 32-42

organization to explore and discover beyond stereotype research predominantly unfold on human resources capital in the organization. The research is profound to a government organization as it is a pioneer research conducted to evaluate the current counter violent extremism program introduced by the Task Force team. The research shall establish itself as a platform for studies to be conducted in diverse avenues to explore the dynamics of human dimension particularly dealing with violent extremism domain. The contributions of this research towards improved policies in the organization are as follows:

a. Formulate a systematic and comprehensive schedule of counter violent extremism program to be integrated with other services in the organization for further enhancement of the existing program.

b. A conceptual research model may be formulated based on the researcher study evaluation process and case dynamics matrix presented as guidelines to formulate structural flow of effective CVE program in future. This may be implemented at all levels of an organization either in headquarters or unit disposition.

c. The researcher has identified some major themes in the findings that indicate the inclination of military personnel towards these aspects. Hence, this enables a more diligent and coherent approach likelihood to be undertaken for problem solving solutions in future direction.

d. Anticipative and develop a cohesive response feedback from the audience after witnessing the road show program (CVE program), discuss in-depth on the methodology, initiate multiple efforts to examine the issue constructively which can result positive outcomes in addressing this issue.

e. Introduced conducive yet friendly method of open forum discussion, arguments and presentation on the topic of violent extremism and terrorism impact to the military family to nurture and educate the military society with relevant perspectives and appropriate response in confronting with this issue.

f. The essentiality of imparting useful and practical information thus improving the method of gaining knowledge with adequate resources available that substantiates towards the conscientiousness of acquiring accurate and relevant information from reliable sources available.

g. Some extensive findings on internal management issues discovered at unit level to incapacitate this issue at an early stage (preventive measures) and addressing the issues of executing the improved CVE program frequently in all locations in the organization.

\section{CONCLUSION}

Certainly, at this stage the process of conducting the study becomes evident and denotes such interesting manner to explore and discover more eventualities accordingly. Therefore, it is imperative to study the predicament concept of violent extremism threat subjected in the organizational internal environment. The highlight of the study is to comprehend the current stand of violent extremism threat in the organization thus proposing improved CVE mechanism to be implemented for the benefit of the organization. This study justifies the researcher's intention to conduct extensive social science method of human resources dimension phenomenon in any government or non-government organization with regards to violent extremism conduct. As such the need to re-evaluate the counter measures of CVE programs require the collaborative effort of government sector, non-governments sectors, civil society, private sectors and other pertinent organization [31].

As such, this research would certainly establish lenses for scrutiny thus magnifies quantum studies to be elaborated in the field of violent extremism specifically in any organization as there are insufficient lack of research being conducted from academic bearing. Proper guidance and extensive support from internal and external parties in the establishment will ensure decisive collaboration of research to prevail in future endeavors. A diverse spectrum of exploration research can be yielded to garner elusive equilibrium of knowledge enhancement among all government personnel to face the uncertain future undertaking posture of this particular field.

\section{REFERENCES:}

[1] Jackson R., Murphy E., Poynting S. (2010). Contemporary State Terrorism. Theory and practice. Routledge Taylor and Francis Group, New York.

[2] Gunaratna R. (2018). Counter Terrorist Trends and Analyses. Global Threat Forecast. International Centre for Political Violence and Terrorism Research, 1(10).

[3] Ze Li, Duoyong Sun,Bo Li, Zhanfeng Li \& Aobo Li (2018). Terrorist Group Behavior Prediction by Wavelet Transform-Based Pattern Recognition, Discrete Dynamics in Nature

and Society

[4] Czinkota, M. R., Knight, G. A., \& Liesch, P. W. (2004). Terrorism and International Business. In G. G. S. Suder (Ed.), Terrorism and the International Business Environment: 
Mohd Nazari \& Nizlan/International Journal of Business and Management, 3(2) 2019, Pages: $32-42$

The Security- Business Nexus (43-57). Northampton, MA: Edward Elgar.

[5] Reade, C. (2009). Human resource management implications of terrorist threats to firms in the supply chain. International Journal of Physical Distribution and Logistics Management, 39, 469-485.

[6] Sawalha, I. H. (2017), A Context-Centred, Root Cause Analysis of Contemporary Terrorism, Disaster Prevention and Management: An International Journal, 26(2), 1-29.

[7] Conway M. (2016). Determining the Role of the Internet in Violent Extremism and Terrorism: Six Suggestions for Progressing Research. Studies in Conflict \& Terrorism.

[8] Field, A. (2016). The Dynamics of Terrorism and Counterterrorism: Understanding the Domestic Security Dilemma. Studies in Conflict \& Terrorism, 40(6), 470-483.

[9] Richards, A. (2014) Conceptualizing Terrorism, Studies in Conflict \& Terrorism, 37(3), 213-236,

[10] Jani M.H (2017). Annual Threat Assessment 2017, Counter Terrorist Trends and Analyses (CTTA), International Centre for Political Violence and Terrorism Research (ICPVTR), S. Rajaratnam School of International Studies (RSIS), Nanyang Technological University, Singapore.

[11] Matveev, A. V. (2016). Perspective Use of Modeling for Information Counter-Terrorism, International Journal of Humanities and Cultural Studies, 2561-2567.

[12] Feridun M., \& Shahbaz M. (2010). Fighting Terrorism. Are Military Measures Effective? Empirical Evidence from Turkey. Defence and Peace Economics 21(2), 193-205.

[13] Bourne Jr L.E., Healy A.F., Beer F.A. (2003). Military Conflict and Terrorism. General Psychology Informs International Relations. Review of General Psychology, 7(2), 189-202.

[14] Defence Intelligence Staff Division (DISD), Ministry of Defence (MINDEF), Malaysia (2017).

[15] Yin R.K (2016). Qualitative Research from Start to Finish. 2nd Edition. The Guildford Press, New York

[16] Zainal. Z (2007). Case study as a Research Method. Jurnal Kemanusiaan, 9.

[17] Creswell, J.W. (2007). Qualitative inquiry \& research design: Choosing among five approaches, 2nd ed, Thousand Oaks, CA: Sage.

[18] Collingridge, D. S., \& Gantt, E. E. (2008). The quality of qualitative research. American Journal of Medical Quality, 23(5), 389-395.

[19] Wimpenny, P., \& Gass, J. (2000). Interviewing in phenomenology and grounded theory: Is there a difference? Journal of Advanced Nursing, 31(6), 1485-1492.
[20]

Kallio H., Pieti A.A.M, Johnson M. \& Kangasniemi M. (2016). Systematic methodological review: developing a framework for a qualitative semi-structured interview guide. Journal of Advanced Nursing, $1-11$.

[21] Oliver D.G, Serovich J.M \& Mason T.L (2005). Constraints and Opportunities with Interview Transcription: Towards Reflection in Qualitative Research. Social Forces, 84(2), 1273-1289.

[22] Davidson C. (2009). Transcription: Imperatives for Qualitative Studies. International Journal of Qualitative Methods. 8(2).

[23] Braun V., \& Clarke V. (2006). Using thematic analysis in psychology. Qualitative Research in Psychology, 3, 77-101.

[24] King, N. (2004). Using templates in the thematic analysis of text. Essential guide to qualitative methods in organizational research, 257-270. London, UK: Sage

[25] Nowell L.S, Norris J.M, White D.E \& Moules N.J (2017). Thematic Analysis: Striving to Meet the Trustworthiness Criteria, International Journal of Qualitative Methods, $16,1-13$

[26] Saldana J. (2009), The Coding Manual for Qualitative Researchers, London, UK: Sage Publications Ltd.

[27] Ryan M. E. (2009) Making visible the coding process: Using qualitative data software in a post-structural study. Issues in Educational Research, 19(2). 142- 161.

[28] Miles M.B., Huberman A.M., Saldana J. (2014). Qualitative Data Analysis. A Method Sourcebook, California, USA: Sage Publication Ltd.

[29] Braun V., \& Clarke V. (2013). Successful Qualitative Research. A practical guide for beginners. London: Sage Publication Ltd.

[30] Mohamed Ali R.B., Moss S.A., Barrelle K., Lentini P., (2017). Does the pursuit of meaning explain the initiation, escalation, and disengagement of violent extremists? Aggression and Violent Behavior

[31] Ponelis S. R. (2015). Using interpretive qualitative case studies for exploratory research in doctoral studies: A case of Information Systems research in small and medium enterprises. International Journal of Doctoral Studies, 10, 535-550.

[32] Gielen A.J. (2017): Countering Violent Extremism: A Realist Review for Assessing What Works, for Whom, in What Circumstances, and How? Terrorism and Political Violence.

[33] Tierney M. (2017) Combating homegrown extremism: assessing common critiques and new approaches for CVE in North America, Journal of Policing, Intelligence and Counter Terrorism, $\quad 12(1), \quad 66-73$. 